\title{
PENENTUAN PREMI BULANAN ASURANSI KESEHATAN BERJANGKA PERAWATAN RUMAH SAKIT UNTUK PERORANGAN
}

\author{
EHA ESPINOZA \\ Program Studi Matematika, \\ Fakultas Matematika dan Ilmu Pengetahuan Alam, \\ Kampus UNAND Limau Manis Padang, Indonesia \\ email : ehaespinoza@outlook.co.id
}

\begin{abstract}
Abstrak. Asuransi kesehatan perawatan rumah sakit adalah asuransi yang memberikan santunan kesehatan kepada seseorang (tertanggung) berupa sejumlah uang untuk biaya pengobatan dan perawatan bila diluar kehendaknya ia terserang penyakit. Salah satu jenis asuransi kesehatan perawatan rumah sakit berdasarkan waktu pertanggungannya adalah asuransi berjangka, dimana waktu pertanggungannya berjangka selama $n$ tahun. Besarnya premi yang dibayarkan dapat dilakukan secara tunggal ataupun berkala, yaitu tahunan, semesteran, triwulan, ataupun bulanan. Perhitungan premi bulanan untuk asuransi kesehatan berjangka perawatan rumah sakit diselesaikan dengan menentukan terlebih dahulu nilai sekarang dari anuitas hidup pecahan atau anuitas hidup dengan pembayaran $m$ kali setahun dan premi tunggalnya.
\end{abstract}

Kata Kunci: Asuransi kesehatan perawatan rumah sakit, asuransi berjangka, premi, anuitas hidup dengan pembayaran $m$ kali setahun

\section{Pendahuluan}

Kesehatan adalah hak asasi setiap manusia. Manusia tentu ingin agar tubuhnya tetap sehat sehingga dapat melakukan segala aktifitas dengan baik dan lancar. Akan tetapi, risiko sakit tidak ada yang mengetahui kapan dan kepada siapa akan terjadi. Selain itu, sekarang ini biaya kesehatan semakin melambung tinggi. Orang kaya sekalipun dapat kehilangan hartanya untuk membiayai penyembuhan penyakitnya dikarenakan tidak ada yang mengetahui seberapa besar biaya yang akan dikeluarkan. Oleh karena itu, diperlukan suatu persiapan untuk mengatasi risiko tersebut. Hal tersebut dapat dilakukan dengan berpartipasi dalam asuransi kesehatan.

Melalui asuransi kesehatan, biaya pengobatan dan perawatan yang diderita oleh peserta asuransi (tertanggung) akan dibayarkan oleh pihak perusahaan asuransi (penanggung). Maka dari itu, peserta asuransi berkewajiban untuk membayar sejumlah uang atau yang disebut dengan premi kepada pihak perusahaan asuransi. Pembayaran premi asuransi dapat dilakukan sekaligus (tunggal) atau secara berkala, yaitu tahunan, semesteran, ataupun bulanan. Untuk menentukan besarnya premi yang harus dibayar oleh peserta asuransi diperlukan anuitas hidup yang dipengaruhi oleh percepatan mortalita, peluang hidup, dan peluang meninggal dari peserta asuransi. Pada tulisan ini akan dibahas tentang penentuan premi bulanan 
asuransi kesehatan berjangka perawatan rumah sakit untuk perorangan dengan menggunakan anuitas hidup dengan pembayaran $m$ kali setahun.

\section{Anuitas Hidup dengan Pembayaran $m$ Kali Setahun}

Anuitas hidup dengan pembayaran $m$ kali setahun adalah anuitas hidup yang pembayarannya dilakukan $m$ kali setahun dengan selang pembayarannya dilakukan setiap $\frac{1}{m}$ tahun (misal $m=12$ ), berarti pembayarannya dilakukan setiap bulan. Pembayaran ini dilakukan selama peserta asuransi (tertanggung) masih hidup.

Adapun anuitas yang digunakan dalam tulisan ini adalah anuitas hidup berjangka dengan pembayaran $m$ kali setahun. Nilai sekarang dari anuitas hidup awal berjangka $n$ tahun dengan pembayaran $m$ kali setahun untuk peserta asuransi berusia $x$ tahun dinyatakan dengan [4]:

$$
\ddot{a}_{x: n \mid}^{(m)}=\frac{N_{x}-N_{x+n}}{D_{x}}-\frac{m-1}{2 m}\left(1-\frac{D_{x+n}}{D_{x}}\right) .
$$

Sedangkan nilai sekarang dari anuitas hidup akhir berjangka $n$ tahun dengan pembayaran $m$ kali setahun untuk peserta asuransi berusia $x$ tahun dinyatakan dengan $[4]$ :

$$
a_{x: n \mid}^{(m)}=\frac{N_{x+1}-N_{x+n+1}}{D_{x}}+\frac{m-1}{2 m}\left(1-\frac{D_{x+n}}{D_{x}}\right)
$$

\section{Premi Asuransi Kesehatan Berjangka Perawatan Rumah Sakit untuk Perorangan}

Asuransi kesehatan perawatan rumah sakit adalah asuransi yang memberikan santunan kesehatan kepada peserta asuransi (tertanggung) berupa sejumlah uang untuk biaya pengobatan dan perawatan bila diluar kehendaknya ia terserang penyakit.

Premi asuransi adalah sejumlah uang yang dibayarkan oleh peserta asuransi (tertanggung) kepada pihak perusahaan asuransi (penanggung) sehubung dengan adanya perjanjian pertanggungan yang dituangkan dalam polis asuransi. Berdasarkan waktu pembayarannya, premi dapat dibayarkan sekaligus(tunggal) atau dapat pula dibayarkan secara berkala, misalkan setiap tahun, setiap semester, atau setiap bulan.

Premi tunggal adalah premi asuransi yang dibayarkan sekaligus pada waktu polis asuransi disetujui. Selanjutnya, tidak ada lagi pembayaran premi hingga masa polis asuransi berakhir. Premi tunggal asuransi kesehatan berjangka perawatan rumah sakit untuk peserta asuransi berusia $x$ tahun, dengan $T_{x}^{s h}$ menyatakan rata-rata jumlah hari perawatan rumah sakit dan $q_{x}^{s h}$ menyatakan kemungkinan dirawat di rumah sakit dengan jangka waktu perlindungan selama $n$ tahun dinyatakan dengan $[3]:$

$$
B_{x: \bar{n} \mid}^{1}=\sum_{t=0}^{n-1} v^{t+\frac{1}{2}}{ }_{t} p_{x} q_{x+t}^{s h} T_{x+t}^{s h} .
$$


Dengan menggunakan simbol komutasi diperoleh persamaan berikut.

$$
B_{x: \bar{n} \mid}^{1}=\frac{1}{D_{x}} \sum_{t=0}^{n-1}\left(\bar{D}_{x+t} q_{x+t}^{s h} T_{x+t}^{s h}\right) .
$$

Premi bulanan adalah premi asuransi yang dibayarkan setiap bulan oleh peserta asuransi selama jangka waktu $n$ tahun. Anuitas yang digunakan untuk premi ini adalah anuitas hidup berjangka dengan pembayaran $m=12$ kali setahun. Perhitungan premi bulanan diperoleh dari persamaan dasar perhitungan premi, yaitu nilai sekarang premi sama dengan nilai sekarang santunan. Premi bulanan yang pembayarannya dilakukan setiap awal bulan selama $n$ tahun oleh peserta asuransi berusia $x$ tahun dinyatakan dengan

$$
\ddot{H}_{x: \bar{n} \mid}^{(12)}=R \frac{B_{x: \bar{n} \mid}^{1}}{12 \ddot{a}_{x: \bar{n} \mid}^{(12)}} .
$$

Berdasarkan persamaan (2.1) dan persamaan (3.2), maka persamaan di atas dapat ditulis sebagai berikut

$$
\ddot{H}_{x: n \mid}^{(12)}=R \frac{\sum_{t=0}^{n-1}\left(\bar{D}_{x+t} q_{x+t}^{s h} T_{x+t}^{s h}\right)}{12\left[N_{x}-N_{x+n}-\frac{11}{24}\left(D_{x}-D_{x+n}\right)\right]} .
$$

Sedangkan premi bulanan yang pembayarannya dilakukan setiap akhir bulan selama $n$ tahun oleh peserta asuransi berusia $x$ tahun dinyatakan dengan

$$
H_{x: \bar{n} \mid}^{(12)}=R \frac{B_{x: \bar{n} \mid}^{1}}{12 a_{x: \bar{n} \mid}^{(12)}} .
$$

Berdasarkan persamaan (2.2) dan persamaan (3.2), maka persamaan di atas dapat ditulis sebagai berikut

$$
H_{x: n \mid}^{(12)}=R \frac{\sum_{t=0}^{n-1}\left(\bar{D}_{x+t} q_{x+t}^{s h} T_{x+t}^{s h}\right)}{12\left[N_{x+1}-N_{x+n+1}+\frac{11}{24}\left(D_{x}-D_{x+n}\right)\right]}
$$

\section{Ilustrasi Kasus}

Seorang laki-laki membeli polis asuransi kesehatan perawatan rumah sakit selama 20 tahun dengan santunan Rp. 700.000,00/hari untuk biaya kamar dan Rp. 150.000,00/hari untuk biaya kunjungan dokter maksimal 180 hari per tahun. Dengan menggunakan Tabel Mortalitas Indonesia Tahun 1999 untuk laki-laki, suku bunga $6 \%$ per tahun, dan Tabel RP-2000 Male Combined Healthy, maka premi bulanan yang harus dibayarkan setiap awal bulan dapat dihitung dengan langkahlangkah berikut.

(1) Apabila laki-laki tersebut membeli polis asuransi pada usia 27 tahun. 
(a) Nilai sekarang dari anuitas awal hidup berjangka 20 tahun dengan pembayaran 12 kali setahun adalah:

$$
\begin{aligned}
\ddot{a}_{27: \overline{20 \mid}}^{(12)} & =\frac{N_{27}-N_{47}}{D_{27}}-\frac{12-1}{24}\left(1-\frac{D_{47}}{D_{27}}\right), \\
& =\frac{3565364,88465-1969732,21091}{84899,56844}-\frac{11}{24}\left(1-\frac{73748,87966}{84899,56844}\right), \\
& =18,73416 .
\end{aligned}
$$

(b) Besarnya premi tunggal asuransi kesehatan berjangka 20 tahun perawatan rumah sakit adalah:

$$
\begin{aligned}
R B_{27: \overline{20 \mid}}^{1} & =\left(150000+700000+\frac{1}{180}[10000000]\right) \frac{1}{D_{27}} \sum_{t=0}^{19}\left(\bar{D}_{27+t} q_{27+t}^{s h} T_{27+t}^{s h}\right), \\
& =R p .2 .910 .333,615 .
\end{aligned}
$$

(c) Besarnya premi bulanan asuransi kesehatan berjangka 20 tahun perawatan rumah sakit yang dibayarkan setiap awal bulan adalah:

$$
\begin{aligned}
\ddot{H}_{27: \overline{20 \mid}}^{(12)} & =R \frac{B_{27: \overline{20 \mid}}^{1}}{12 \ddot{a}_{27: \overline{20 \mid}}^{(12)}} \\
& =\frac{R p \cdot 2.910 .333,615}{12(18,73416)}, \\
& =R p .12 .945,75392 .
\end{aligned}
$$

(2) Apabila laki-laki tersebut membeli polis asuransi pada usia 40 tahun.

(a) Nilai sekarang dari anuitas awal hidup berjangka 20 tahun dengan pembayaran 12 kali setahun adalah

$$
\begin{aligned}
\ddot{a}_{40: \overline{20 \mid}}^{(12)} & =\frac{N_{40}-N_{60}}{D_{40}}-\frac{12-1}{24}\left(1-\frac{D_{60}}{D_{40}}\right), \\
& =\frac{2503125,62565-1074068,73219}{77937,78409}-\frac{11}{24}\left(1-\frac{62078,05715}{77937,78409}\right), \\
& =18,24260 .
\end{aligned}
$$

(b) Besarnya premi tunggal asuransi kesehatan berjangka 20 tahun perawatan rumah sakit adalah:

$$
\begin{aligned}
R B_{40: \overline{20 \mid}}^{1} & =\left(150000+700000+\frac{1}{180}[10000000]\right) \frac{1}{D_{40}} \sum_{t=0}^{19}\left(\bar{D}_{40+t} q_{40+t}^{s h} T_{40+t}^{s h}\right), \\
& =R p .7 .489 .345,258 .
\end{aligned}
$$

(c) Besarnya premi bulanan asuransi kesehatan berjangka 20 tahun perawatan rumah sakit yang dibayarkan setiap awal bulan adalah

$$
\begin{aligned}
\ddot{H}_{40: \overline{20 \mid}}^{(12)} & =R \frac{B_{40: \overline{20 \mid}}^{1}}{12 \ddot{a}_{40: \overline{20 \mid}}^{(12)}}, \\
& =\frac{R p \cdot 7.489 .345,258}{12(18,24260)}, \\
& =R p .34 .211,79496 .
\end{aligned}
$$


(3) Apabila laki-laki tersebut membeli polis asuransi pada usia 65 tahun.

(a) Nilai sekarang dari anuitas awal hidup berjangka 20 tahun dengan pembayaran 12 kali setahun adalah:

$$
\begin{aligned}
\ddot{a}_{65: \overline{20 \mid}}^{(12)} & =\frac{N_{65}-N_{85}}{D_{65}}-\frac{12-1}{24}\left(1-\frac{D_{85}}{D_{65}}\right) \\
& =\frac{776741,79704-58478,90660}{55193,02040}-\frac{11}{24}\left(1-\frac{12277,71539}{55193,02040}\right), \\
& =12,65728 .
\end{aligned}
$$

(b) Besarnya premi tunggal asuransi kesehatan berjangka 20 tahun perawatan rumah sakit adalah:

$$
\begin{aligned}
R B_{65: \overline{20 \mid}}^{1} & =\left(150000+700000+\frac{1}{180}[10000000]\right) \frac{1}{D_{65}} \sum_{t=0}^{19}\left(\bar{D}_{65+t} q_{65+t}^{s h} T_{65+t}^{s h}\right), \\
& =R p .51 .257 .822,32 .
\end{aligned}
$$

(c) Besarnya premi bulanan asuransi kesehatan berjangka 20 tahun perawatan rumah sakit yang dibayarkan setiap awal bulan adalah:

$$
\begin{aligned}
\ddot{H}_{65: \overline{20 \mid}}^{(12)} & =R \frac{B_{65: \overline{20 \mid}}^{1}}{12 \ddot{a}_{65: \overline{20 \mid}}^{(12)}} \\
& =\frac{R p .51 .257 .822,32}{12(12,65728)} \\
& =R p .337 .472,6667
\end{aligned}
$$

Dari simulasi kasus yang telah dilakukan, dengan uang santunan yang sama, besarnya premi bulanan yang dibayarkan oleh peserta asuransi berusia 27 tahun lebih kecil, yaitu Rp. 12.945,75342 dibandingkan dengan besarnya premi bulanan yang dibayarkan oleh peserta asuransi berusia 65 tahun, yaitu Rp. 337.472,6667. Sehingga dapat diketahui bahwa semakin tinggi usia peserta asuransi dalam mengikuti asuransi, maka besarnya premi yang harus dibayarkan semakin besar. Hal ini dikarenakan semakin tingginya peluang sakit dan peluang meninggal dari peserta asuransi yang berusia tinggi.

\section{Kesimpulan}

Besarnya premi yang dibayarkan peserta asuransi (tertanggung) ditentukan oleh usia peserta asuransi saat membeli polis asuransi. Semakin tinggi usia peserta asu ransi dalam mengikuti asuransi, maka besarnya premi yang harus dibayarkan semakin besar. Hal ini dikarenakan semakin tingginya peluang sakit dan peluang meninggal dari peserta asuransi yang berusia tinggi.

\section{Daftar Pustaka}

[1] Anonim. 2000. RP-2000 Male Combined Healthy. Atlanta: Society of Actuaries, Office Management Institute LOMA. 
[2] Futami, T. 1993. Matematika Asuransi Jiwa Bagian I. Diterjemahkan oleh: Gatot Herliyanto. Tokyo: Incorprated Foundation Oriental Life Insurance Cultural Develompent Center.

[3] Futami, T. 1994. Matematika Asuransi Jiwa Bagian II. Diterjemahkan oleh: Gatot Herliyanto. Tokyo: Incorprated Foundation Oriental Life Insurance Cultural Develompent Center.

[4] Larson, R.E. dan E.A. Gaumnitz. 1962. Life Insurance Mathematics. New York: John Wiley and Sons Inc. 